\title{
MOLECULAR CHARACTERIZATION OF THE 229E STRAIN OF HUMAN
}

\section{CORONAVIRUS}

\author{
Nathalie Arpin and Pierre J. Talbot \\ Virology Research Center \\ Institut Armand-Frappier, Université du Québec \\ 531, boulevard des Prairies \\ Laval, Québec, CANADA H7N 4Z3
}

\begin{abstract}
Human coronaviruses (HCV) cause various respiratory, gastrointestinal and possibly neurological disorders. Very little is known of the molecular biology of these ubiquitous pathogens. We have undertaken the molecular characterization of the prototype 229E strain of $\mathrm{HCV}$. The virus grew to the highest titers on a human embryonic lung cell line (L132) at $33^{\circ} \mathrm{C}$ and purification was optimal on Renografin- $60^{\circledR}$ gradients. Metabolic labeling with $\left[{ }^{35} \mathrm{~S}\right]$ methionine or $\left[{ }^{3} \mathrm{H}\right]$ glucosamine or galactose and analysis by SDSPAGE revealed at least five structural proteins, which could be identified by analogy with murine coronaviruses as follows: the spike glycoprotein (E2/S), in both monomeric (88-97 $\mathrm{kDa}$ ) and dimeric (190-200) forms, the nucleoprotein $(\mathrm{N})$ at $52-53 \mathrm{kDa}$ and the matrix protein $(\mathrm{E} 1 / \mathrm{M})$, in both glycosylated $(25-26 \mathrm{kDa})$ and non-glycosylated $(20-22 \mathrm{kDa})$ forms. Monomeric, dimeric and multimeric $(>200 \mathrm{kDa})$ forms of E2/S incorporated glucosamine and galactose, whereas only galactose was incorporated into E1/M. Multimers of E1/M, with apparent molecular masses of 44,74 and $140 \mathrm{kDa}$, were formed in the absence of a reducing agent.
\end{abstract}

\section{INTRODUCTION}

Human coronaviruses belong to either one of two antigenic groups, represented by the prototype strains $229 \mathrm{E}$ and $\mathrm{OC}^{2} 3^{1}$. They are responsible for as much as $25 \%$ of common colds ${ }^{2}$, and a possible involvement in neurological disorders was suggested by the observation of corona-like virus particles in the brain of one multiple sclerosis (MS) patient $^{3}$, the isolation of two coronaviruses from MS brain tissue passaged in mice ${ }^{4}$ and the detection of intrathecal antibodies against coronaviruses in MS patients 5 . Nevertheless, our limited knowledge of the molecular structure and biology of human coronaviruses and the lack of molecular probes have not yet allowed a verification of their medical importance. We report here our initial studies on the molecular structure of the $229 \mathrm{E}$ strain of human coronavirus.

\section{METHODS}

\section{$\underline{\text { Cells and virus }}$}

The L132 human embryonic lung cell line 6,7 , the Vero african green monkey kidney cell line and the 229E strain of HCV (HCV-229E) were obtained from the American 
Type Culture Collection (ATCC; Rockville, MD, U.S.A.). The RD151 human rhabdomyosarcoma 8,9 and the HRT18 human adenocarcinoma 10 cell lines were kindly provided by Dr. Arlene R. Collins (State University of New York, Buffalo, NY, U.S.A.) and Dr. David A. Brian (University of Tennessee, Knoxville, TN, U.S.A.), respectively. The IMHP human embryonic lung cell line was obtained fron the Tissue Culture Service of this Institute. Cells were grown as monolayers at $37^{\circ} \mathrm{C}$ in Earle's minimum essential medium : Hank's M199 (1:1, v/v) containing $0.13 \%(\mathrm{w} / \mathrm{v})$ sodium bicarbonate, $50 \mu \mathrm{g} / \mathrm{ml}$ of gentamicin and 5\% (v/v) fetal bovine serum (FBS). The virus was plaque-purified twice and a stock obtained by three serial passages at an MOI of 0.001 . Infectious titers were determined by plaque assay as described ${ }^{11}$, except that plaques were revealed after a 7-day incubation period of infected L132 cells at $33^{\circ} \mathrm{C}$. Viral infections were performed on halfconfluent cell monolayers in medium which had a FBS content reduced to $1 \%(\mathrm{v} / \mathrm{v})$. For viral growth curves in L132 cells, infectious titers were obtained by plaque assay with both culture medium clarified at $1500 \times \mathrm{g}$ for $7 \mathrm{~min}$ (extracellular virus) and cell monolayers lysed by three cycles of freezing at $-70^{\circ} \mathrm{C}$ and thawing at $37^{\circ} \mathrm{C}$ (intracellular virus).

\section{Radiolabeling of viral polypeptides}

The infectious titer of the HCV-229E stock was concentrated after a fourth passage at low MOI in L132 cells. The medium, harvested at $43 \mathrm{hrs}$ p.i., was clarified by centrifugation at $10,000 \mathrm{x}$ g for $20 \mathrm{~min}$ and virus pelleted at $100,000 \mathrm{x}$ g for $90 \mathrm{~min}$. Resuspension into a small volume of culture medium boosted the viral titer from $1.2 \times 10^{6}$ to $2.6 \mathrm{x}$ $10^{8} \mathrm{PFU} / \mathrm{ml}$. This allowed infection of cells at a higher MOI, in order to optimize the incorporation of radiolabeled precursors into viral polypeptides. At $4 \mathrm{hrs}$ after infection of cells with $\mathrm{HCV}-229 \mathrm{E}$ at an MOI of 1 , either $0.33 \mathrm{mCi} / \mathrm{ml}$ of $\left[{ }^{35} \mathrm{~S}\right] \mathrm{methionine}\left({ }^{35} \mathrm{~S}-E\right.$. coli hydrolysate containing $70 \%$ methionine) or $70 \mu \mathrm{Ci} / \mathrm{ml}$ of $\left[{ }^{3} \mathrm{H}\right]$ glucosamine or $\left[{ }^{3} \mathrm{H}\right]$ galactose (ICN, Ville St-Laurent, $\mathrm{PQ}$, Canada) was added to the culture medium.

\section{Virus purification}

Infected fluids were harvested at $43 \mathrm{hrs}$ p.i., clarified by centrifugation at $10,000 \mathrm{x}$ $g$ for $20 \mathrm{~min}$, and virus precipitated with $10 \%(\mathrm{w} / \mathrm{v})$ polyethylene glycol in the presence of $0.5 \mathrm{M} \mathrm{NaCl}$. After centrifugation at $10,000 \times \mathrm{g}$ for $30 \mathrm{~min}$, the pellet was resuspended in TMEN buffer (50 mM Tris-acid-maleate, $\mathrm{pH} 6.2,0.1 \mathrm{M} \mathrm{NaCl}, 1 \mathrm{mM}$ EDTA) and applied to a discontinuous 10 and $50 \%$ (v/v) Renografin-60 ${ }^{\circledR}$ (Squibb Canada, Montréal, PQ, Canada) gradient, which was centrifuged at $148,000 \times \mathrm{g}$ for $2 \mathrm{hrs}$. The viral band was further purified on a continuous gradient of the same material, centrifuged at the same speed for 18 hrs. In one experiment, the following gradient materials were compared to Renografin- $60^{\circledR}$ for the optimization of viral purification: $10-50 \%(\mathrm{w} / \mathrm{w})$ sucrose or potassium tartrate or $10-50 \%$ (w/v) Nycodenz ${ }^{\circledR}$ (Accurate Chemicals, Westbury, NY, U.S.A.).

\section{Polyacrylamide gel electrophoresis (SDS-PAGE)}

Samples were resuspended in sample buffer [50 mM Tris- $\mathrm{HCl}, \mathrm{pH} 6.8,1 \%(\mathrm{w} / \mathrm{v})$ sodium dodecyl sulfate (SDS), $1 \%$ (v/v) 2-mercaptoethanol (omitted in one experiement), $10 \%(\mathrm{v} / \mathrm{v})$ glycerol, $0.003 \%$ (w/v) bromophenol blue] and treated at $100{ }^{\circ} \mathrm{C}$ for $2 \mathrm{~min}$. Polypeptides were separated on 7 to $15 \%(\mathrm{w} / \mathrm{v})$ polyacrylamide gels 12 and revealed by fluorography with Enlightning ${ }^{\circledR}$ (Dupont, Montréal, PQ, Canada). Radiolabeled molecular weight standards were used to estimate the size of viral polypeptides.

\section{RESULTS}

The initial step in our molecular characterization of HCV-229E consisted in optimizing virus growth and purification conditions. A viral growth curve was established in L132 cells at $37^{\circ} \mathrm{C}$, as shown in Fig. 1 . After infection at low MOI, infectious virus was detectable by $10 \mathrm{hrs}$ p.i. and started to appear in the culture medium at $14 \mathrm{hrs}$ p.i., before reaching a peak at $42-44 \mathrm{hrs}$ p.i.. However, much higher infectious titers could be obtained 


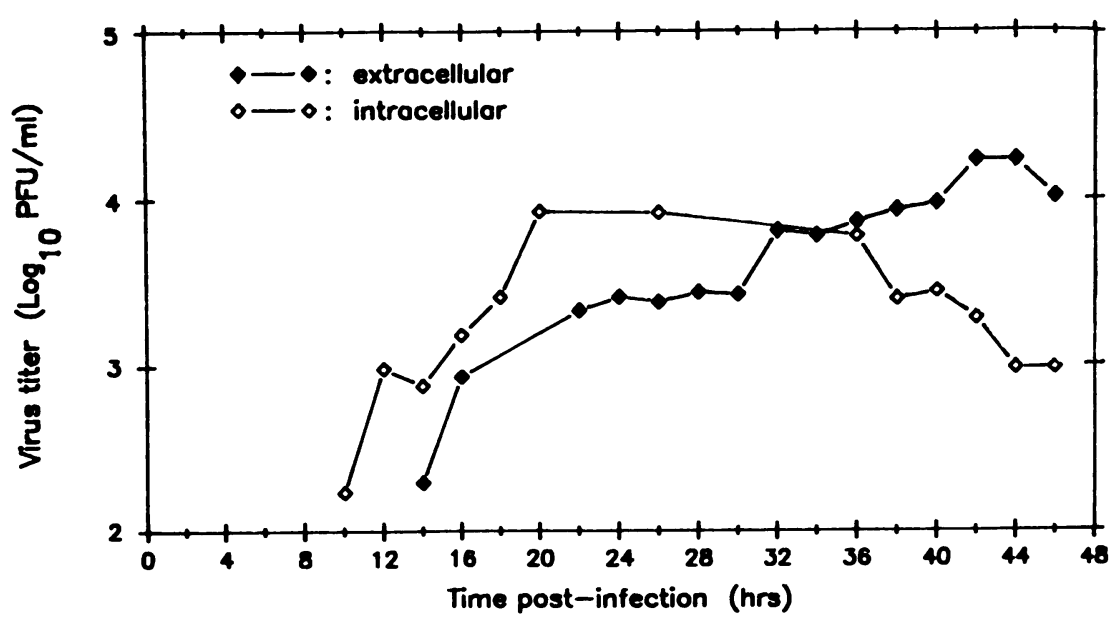

Fig. 1. Growth curve of HCV-229E on L132 cells at $37^{\circ} \mathrm{C}(\mathrm{MOI}=0.001)$

after infection at $33^{\circ} \mathrm{C}$. Growth curves were obtained at this temperature for both intracellular (Fig. 2) and extracellular (Fig. 3) virus. Even though infectious titers were as much as 1000 -fold higher at $33^{\circ} \mathrm{C}$, the growth curves showed a similar time-dependence on the production of infectious virus particles. Moreover, there was no difference in the infectious virus titers obtained at $42-44 \mathrm{hrs}$ after infection at MOIs of $0.01,0.1$ or 1 , although extracellular virus titers were slightly reduced after infection at an MOI of 0.001 . Thus, an MOI of 0.01 was chosen for virus passages, and a time of $43 \mathrm{hrs}$ p.i. determined to be optimal for the obtention of extracellular virions. We then compared the infectious virus titers which could be obtained after infection of various cell lines. As shown in Table 1, given the fact that IMHP cells were more difficult to grow, L132 cells represented the best of the cell lines tested. Finally, of four gradient materials tested for virus purification, Renografin- $60^{\circledR}$ allowed the best recovery of infectious virus and integrity of virions as seen in the electron microscope (data not shown)

Table 1. Growth of HCV-229E on various cell lines

\begin{tabular}{|c|c|c|c|}
\hline Cell line & $\begin{array}{l}\text { Temperature } \\
\left({ }^{\circ} \mathrm{C}\right)\end{array}$ & $\begin{array}{l}\text { Infectious virus titer } \\
\text { (PFU/ml) }\end{array}$ & $\mathrm{n}^{1}$ \\
\hline L132 & 37 & $1.3 \pm 0.7 \times 10^{5}$ & 7 \\
\hline $\begin{array}{l}\text { IMHP } \\
\text { RD151 } \\
\text { Vero } \\
\text { HRT18 }\end{array}$ & $\begin{array}{l}37 \\
37 \\
37 \\
37\end{array}$ & $\begin{array}{l}2.8 \pm 0.2 \times 10^{5} \\
1.2 \leq 20 \times 10^{4} \\
\quad<20 \\
\quad<2\end{array}$ & $\begin{array}{l}2 \\
2 \\
2 \\
2\end{array}$ \\
\hline L132 & 33 & $1.2 \pm 0.9 \times 10^{6}$ & 9 \\
\hline
\end{tabular}

1 number of experiments 


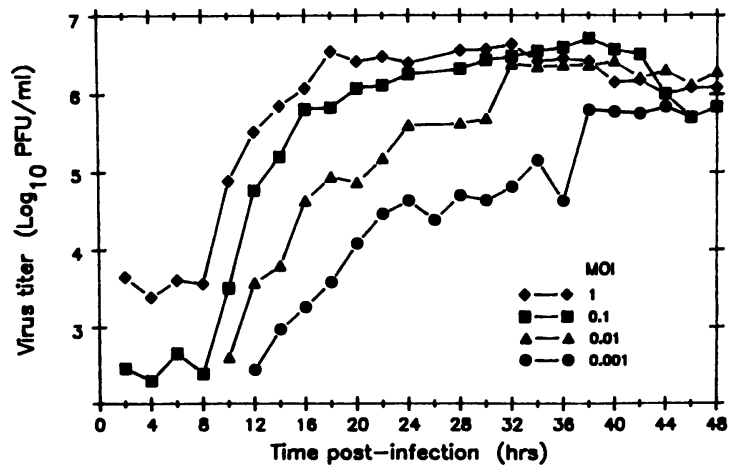

Fig. 2. Growth curves of HCV-229E on L132 cells at $33^{\circ} \mathrm{C}$ and various MOIs (intracellular virus)

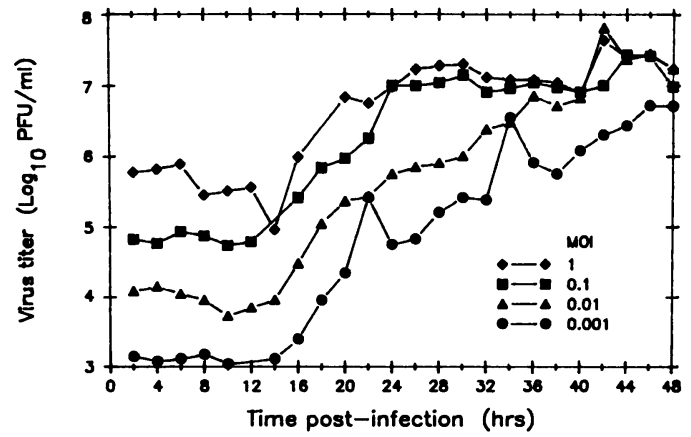

Fig. 3. Growth curves of HCV-229E on L132 cells at $33^{\circ} \mathrm{C}$ and various MOIs (extracellular virus) 


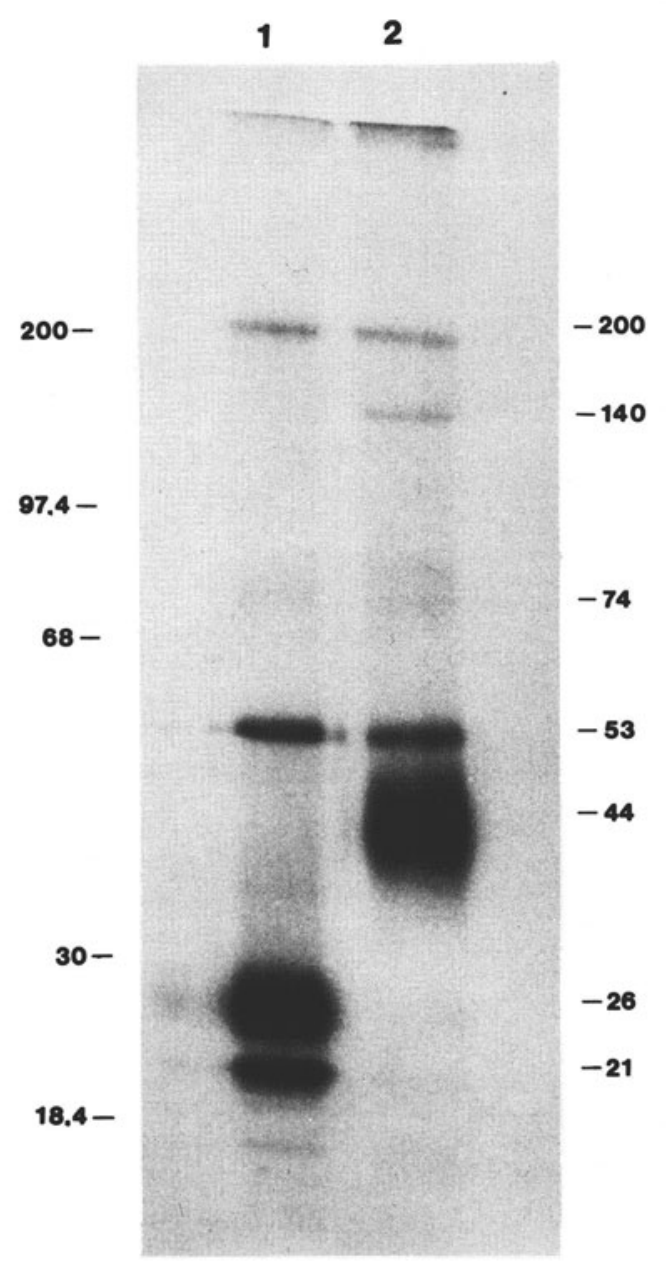

Fig. 4. Effect of reducing agent on $[35$ S $]$ methionine-labeled HCV-229E polypeptides. Sample buffer for SDS-PAGE contained (lane 1) or was free of (lane 2) 2-mercaptoethanol. The migration of radiolabeled molecular weight standards is shown on the left and the calculated molecular weights of observed viral polypeptides is shown on the right.

Having optimized virus growth and purification conditions, we undertook the molecular characterization of the viral proteins. Labeling of HCV-229E with [35S]methionine and analysis of purified virions by SDS-PAGE showed four major viral polypeptides which migrated with apparent molecular masses of 200, 53, 26 and $21 \mathrm{kDa}$. These masses varied slightly between experiments and the following ranges were observed: 190-200, 52$53,25-26$ and $20-22 \mathrm{kDa}$. An additionnal polypeptide of 88-97 kDa was occasionnally observed. Omission of the reducing agent caused a disappearance of the 26 and $21 \mathrm{kDa}$ molecules and the appearance of 44,74 and $140 \mathrm{kDa}$ polypeptides. 


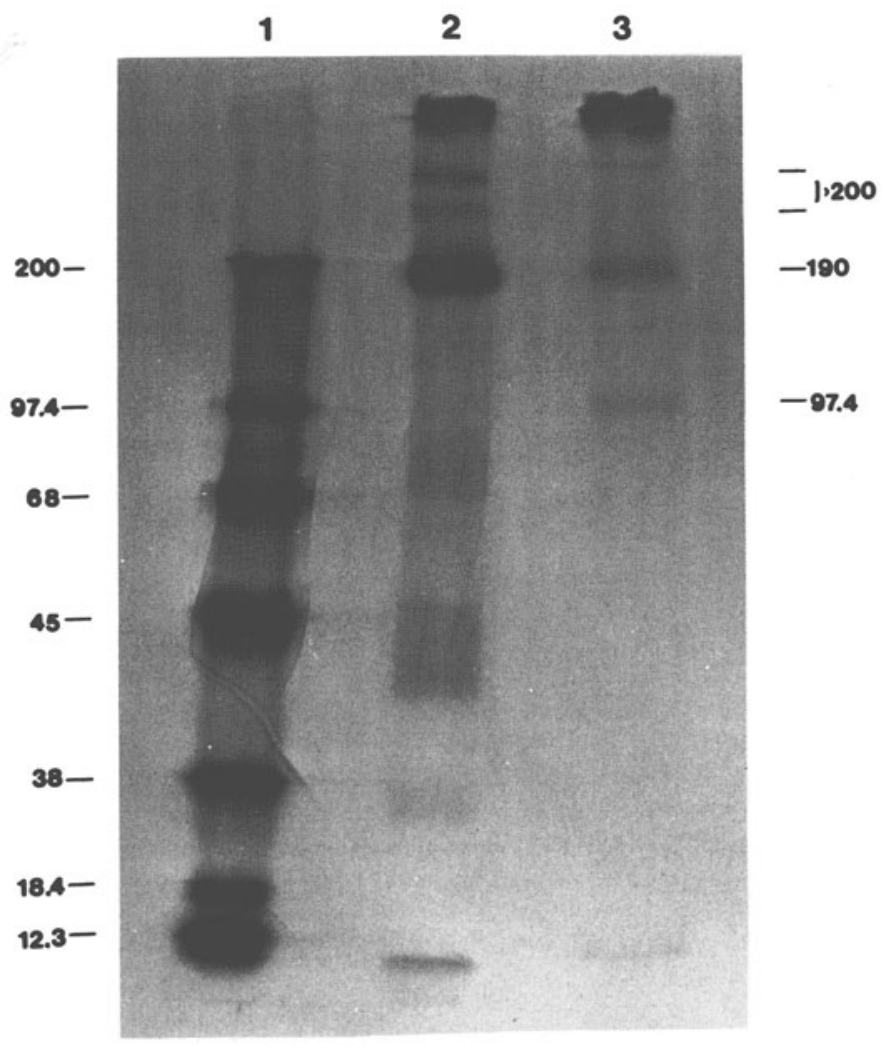

Fig. 5. Labeling of HCV-229E glycoproteins with $\left[{ }^{3} \mathrm{H}\right]$ glucosamine. The migration of radiolabeled molecular weight standards is shown on the left and the calculated molecular weights of observed viral polypeptides is shown on the right.

Finally, the incorporation of radiolabeled sugars was used to identify viral glycoproteins. As shown in Fig. 5, polypeptides of 97 and 190, as well as two large species which migrated above the $200 \mathrm{kDa}$ marker, incorporated $\left[{ }^{3} \mathrm{H}\right]$ glucosamine. On the other hand, $\left[{ }^{3} \mathrm{H}\right]$ galactose was also incorporated into a $26 \mathrm{kDa}$ viral polypeptide (data not shown).

\section{DISCUSSION}

We have shown that the growth of HCV-229E in the human embryonic lung cell line $\mathrm{L} 132$ at $33^{\circ} \mathrm{C}$ after infection at an MOI of at least 0.01 , followed by purification on Renografin- $60^{\circledR}$ gradients, represented the optimal experimental conditions tested for the most efficient recovery of infectious viral particles needed for molecular studies. Growth curves allowed the determination of optimal harvesting times for the analysis of viral structural proteins and will prove invaluable for the study of non-structural proteins. After metabolic radiolabeling with [ 35 S] methionine, four to five structural viral proteins could be identified. By analogy with murine coronaviruses, they could be identified as the spike glycoprotein (E2/S), in both monomeric (88-97 kDa) and dimeric (190-200) forms, the nucleoprotein $(\mathrm{N})$ at $52-53 \mathrm{kDa}$ and the matrix protein $(\mathrm{E} 1 / \mathrm{M})$, in both glycosylated (25-26 $\mathrm{kDa})$ and non-glycosylated (20-22 kDa) forms.

Other authors have identified putative E2/S glycoprotein dimers at 160-196 $\mathrm{kDa}^{13,14,15}$ and monomers at $105 \mathrm{kDa} 13,14$, which is consistent with our observation of 
190-200 and 88-97 $\mathrm{kDa}$. However, the putative E2/S multimers which migrated at $>200$ $\mathrm{kDa}$ after labeling with $\left[{ }^{3} \mathrm{H}\right]$ glucosamine have not been previously observed, although their significance is unclear since they could not be detected after labeling with [ 35 S]methionine. The inconsistent appearance of the putative E2/S monomer of 88-97 $\mathrm{kDa}$ may relate to variations in the presumed proteolytic cleavage of the dimeric form of the molecule.

On the other hand, we have observed an apparently larger nucleoprotein than the previously reported $47-50 \mathrm{kDa}$ molecule $13,14,15$, as well as larger E1/M polypeptides when compared to the previously reported $17-24 \mathrm{kDa}$ molecules $13,14,15$. The only study which reported on the glycosylation of the E1/M protein showed incorporation of $\left[{ }^{14} \mathrm{C}\right]$ glucosamine into a $17 \mathrm{kDa}$ molecule ${ }^{13}$. We have been unable to detect incorporation of glucosamine into the $25-26 \mathrm{kDa}$ putatively glycosylated form of $\mathrm{E} 1 / \mathrm{M}$, although we could confirm glycosylation by the incorporation of $[3 \mathrm{H}]$ galactose. Moreover, we could not observe the 165 and $31 \mathrm{kDa}$ glycoproteins that were previously reported ${ }^{13}$, which is consistent with other studies 14,15 .

The apparent multimerization of the E1/M matrix protein in the absence of a reducing agent has not to our knowledge been observed to date with any coronaviruses. The apparent molecular masses of the observed putative multimers suggest dimers (44 kDa), trimers $(74 \mathrm{kDa})$ and hexamers $(140 \mathrm{kDa})$. Putative dimers were most prominent and their absence in the presence of 2-mercaptoethanol is contrary to the reducing agent - enhanced appearance of a $38 \mathrm{kDa}$ polypeptide of MHV-A5916. Moreover, the predicted primary sequence of the E1/M protein of HCV-229E, deduced from the nucleotide sequence of the cloned gene reveals, unlike other coronaviruses, the presence of only one cysteine residue (P. Jouvenne et al., submitted for publication), which may be available to the formation of intermolecular disulfide bridges. Previous studies with MHV-A59 and HCV-OC43 have estimated the molar ratios of $E 1 / M$ to $E 2 / S$ to be $16: 117$ or $33: 4^{18}$, respectively. Presumably, several E1/M molecules could be joined by intermolecular disulfide bridges and other molecular links and interact with E2/S glycoproteins to stabilize viral peplomers. Thus, it would be conceivable that mutations in the E1/M gene could alter the stability of peplomers, which could alter virus pathogenesis. This would further emphasize the important role of this protein in virus biology, as was recently exemplified by the observation of passive anti- E1/M monoclonal antibody protection from MHV-JHM induced encephalitis ${ }^{19}$, and which would be consistent with the extensive antigenic conservation of E1/M already observed among various strains of murine coronaviruses ${ }^{20}$.

Further molecular studies of human coronaviruses are important to gain a better understanding of their biology and involvement in human disease. Such studies are now in progress.

\section{ACKNOWLEDGMENTS}

This work was supported by grant MT-9203 to P.J. Talbot from the Medical Research Council of Canada. A studentship support to N. Arpin from Institut Armand-Frappier is gratefully acknowledged, as well as a scholarship to P.J. Talbot from the Natural Sciences and Engineering Research Council of Canada. The authors thank the excellent technical assistance of Francine Lambert and Francine Allard.

\section{REFERENCES}

1. M.R. Macnaughton, M.H. Madge, and S.E. Reed, Two antigenic groups of human coronaviruses detected by using enzyme-linked immunosorbent assay, Infect. Immun. 33: 734 (1981).

2. K. McIntosh. Coronaviruses. A comparative review, Curr. Top. Microbiol. Immunol. 63: 85 (1974).

3. R. Tanaka, Y. Iwasaki, and H. Koprowski, Intracisternal virus-like particles in brain of a multiple sclerosis patient, J. Neurol. Sci. 28: 121 (1976). 
4. J.S. Burks, B.L. DeVals, L.D. Jankovsky, and J.C. Gerdes, Two coronaviruses isolated from central nervous system of two multiple sclerosis patients, $\underline{\text { Science }}$ 209: 933 (1980).

5. A. Salmi, B. Ziola, T. Hovi, and M. Reunanen, Antibodies to coronaviruses OC43 and 229E in multiple sclerosis patients, Neurology 32: 292 (1982).

6. E.V. Davis, and V.S. Bolin, Continuous cultivation of isogenous cell lines from the human embryo, Fed. Proc. 19: 386 (1960).

7. G. Chaloner-Larsson, and M. Johnson-Lussenburg, Establishment and maintenance of a persistent infection of L132 cells by human coronavirus strain 229E, Arch. Virol. 69: 117 (1981).

8. R.M. MacAllister, J. Melnyk, J.Z. Finklestein, E.C. Adams, and M.B. Gardner, Cultivation in vitro of cells derived from a human rhabdomyosarcoma, Cancer 24: 520 (1969).

9. O.W. Schmidt, M.K. Cooney, and G.E. Kenny, Plaque assay and improved yield of human coronaviruses in a human rhabdomyosarcoma cell line, J. Clin. Microbiol. 9: 722 (1979).

10. W.A.F. Tompkins, A.M. Watrach, J.D. Schmale, R.M. Schulze, and J.A. Harris, Culture and antigenic properties of newly established cell strains derived from adenocarcinomas of the human colon and rectum, J. Natl. Cancer Inst. 52: 101 (1974).

11. C. Daniel, and P.J. Talbot, Physico-chemical properties of murine hepatitis virus, strain A59, Arch. Virol. 96: 241 (1987).

12. U.K. Laemmli, Cleavage of structural proteins during the assembly of the head of bacteriophage T4, Nature (Lond.) 227: 680 (1970).

13. J.C. Hierholzer, Purification and biophysical properties of human coronavirus 229E, Virology 75: 155 (1976).

14. M.R. Macnaughton, The polypeptides of human and mouse coronaviruses, Arch. Virol. 63: 75 (1980).

15. O.W. Schmidt, and G.E. Kenny, Polypeptides and functions of antigens from human coronaviruses 229E and OC43, Infect. Immun. 35: 515 (1982).

16. L.S. Sturman, Characterization of a coronavirus. I. Structural proteins: Effects of preparative conditions on the migration of protein in polyacrylamide gels, Virology 77: 637 (1977).

17. L.S. Sturman, K.V. Holmes, and J. Behnke, Isolation of coronavirus envelope glycoproteins and interaction with the viral nucleocapsid, J. Virol. 33: 449 (1980).

18. B.G. Hogue, and D.A. Brian, Structural proteins of human respiratory coronavirus OC43, Virus Res. 5: 131 (1986).

19. J.O. Fleming, R.A. Shubin, M.A. Sussman, N. Casteel, and S.A. Stohlman, Monoclonal antibodies to the matrix (E1) glycoprotein of mouse hepatitis virus protect mice from encephalitis, Virology 168: 162 (1989).

20. P.J. Talbot, and M.J. Buchmeier. Antigenic variation among murine coronaviruses: Evidence for polymorphism on the peplomer glycoprotein, E2, Virus Res. 2: 317 (1985). 